\title{
The Not-Boring Talk
}

Elaine Christina Humphrey ${ }^{1}$

1. University of Victoria, Advanced Microscopy Facility, Victoria, Canada.

My talk starts with my usual two goals: no one is to go to sleep and I want at least one "WOW!" from every member of the audience. Fortunately, the subject matter is microscopy so this is normally not a problem. Keeping it to 30 minutes is the challenge.

Over the last $30+$ years, my job has been to encourage usually graduate students to get publishable images and work mostly independent of me. The facilities I have worked in have been open to anyone who wants microscopy to enhance their research. Some of the most interesting projects have been from private researchers looking for verification of their specimen.

One of these projects started in 2004 when a private researcher (Terrence Loychuk) brought in a First Nations wooldog blanket from about 1860. This ongoing project has expanded into about 5 different directions. We have now looked at the materials in about 47 early blankets, Only 42 were wooldog blankets. A pre-contact blanket from Ozette, WA [1] turned out to be wooldog and fireweed. We looked at a mid-1800's blanket from Alaska that had 29 different colors where the black was human hair. The data base of hair and fibre images we built up led to a project looking at a robe trim found in northern $\mathrm{BC}$ that belonged to a man (Kwaday Dan Ts'Inchi [2]) frozen in a glacier maybe 300 years ago. The robe was made of 5 rows of 19 gopher skins beautifully stitched together with moose sinew. There were two tears one of which turned out to be stitched with blue whale sinew. The collar and trim down the front of the robe was too degraded to obtain information from the DNA so scanning electron microscopy was proposed. We have at time of press 47 species that it is not. Still looking!

I used to work mostly with biological samples, one minute talking to someone about brain or heart, or liver or red tide, pollen grains, bacteria, viruses......! These days, most of the samples are materials. Each sample seems to come with its own different preparation method. Thinking outside the box helps.

The weirdest material brought into the lab is still aerogels. They are typically $98 \%$ air, so very difficult to actually see the specimen. With a name like aerogel, you would expect the material to cut easily with a razor blade, like jelly. No, it shatters because it is made of $5-10 \mathrm{~nm}$ silicon dioxide particles like glass! In the sem, when the beam hits it, it swells up and collapses like it is breathing. Weird! NASA used it to collect dust from the tail of a comet. It is an extremely good insulator but the physicists (George Beer and Art Olin) who brought it in, was sending it to the synchrotron. When you hit it with muons (heavy electrons), you get muonium out.

Since we have bragging rights to one of the highest resolution TEMs (Hitachi HF3300) and SEMs (Hitachi SU9000) in the world, we can look at atoms. When you've seen one atom, you've seen them all. Then the fun of microscopy turns to material analysis. X-ray analysis, EELS (Electron Energy Loss), holography (good for number and types of atoms, measuring electrostatic fields, magnetic fields and band gap in semi conductors and ceramics at atomic resolution, as well as phase differences) makes looking at materials even more interesting. Even on the Hitachi S4800 SEM, teaching students from middle school to retirees, how to use the xray system (a Bruker EDS system), is one of the best tools to 
stimulate their interest in Chemistry and how atoms work. Every high school should have a table top SEM in it with xray analysis. Then the demographics of $12-18 \%$ of Grade 12 s interested in science would go up.

When you stimulate enthusiasm in scanning electron microscopy for undergraduates, they give back tenfold. For example, one second year biology student (James Tyrwhitt-Drake) started making animated gifs from SEM images which then went viral on the internet. After he took the SEM workshop which includes half a day of free time on the SEM with his specimen to take away publishable images, he wanted to do more but ran out of money. So, he volunteered in my lab for two years to earn time on the sem. A win-win situation. He had his animated gifs on the Smithsonian website [3].

One of my personal research projects is the accessory boring organ (ABO) in the foot of a muricid gastropod. Ocenebra einacea (a marine snail) that bores holes in oysters. This is the not-so boring, boring organ. The cellular structure is amazing. This project brought in a few more methods such as the ODO technique, an osmium maceration technique, to look at the organelles in 3D in an SEM as well as in $2 \mathrm{D}$ using a tem. In this process, the cellular matrix is extracted leaving the membranous material exposed. In the ABO, mitochondria are large corkscrew shaped organelles with tight, tight cristae. One mitochondrion must be producing huge amounts of adenosine triphosphate (ATP) but that's not all. The cells are so tightly packed with mitochondria, their output of ATP must exceed any mammalian system including the liver and brain put together.

My responsibility for helping our researchers to get their images, has led to a number of collaborations which are still on-going and still give me a thrill. Hopefully I can share some of that enthusiasm with you.

References:

[1] Ozette Archeological Site, https://makahmuseum.com/about/ozette-archaeological-site/

[2] Kwaday Dan Ts'Inchi

https:/www.google.ca/search?q=Kwaday+Dan+Ts\%E2\%80\%99Inchi\&tbm=isch\&source=hp\&sa=X\&v ed=2ahUKEwjN1ZWU9rngAhUPFzQIHWyQAh8QsAR6BAgBEAE\&biw=1169\&bih=623

[3] James Tyrwitt Drake animated gifs on Smithsonian website,

https:/www.smithsonianmag.com/smart-news/electron-microscope-zooms-in-finds-life-on-life-on-life30070438/ (August 22, 2012).

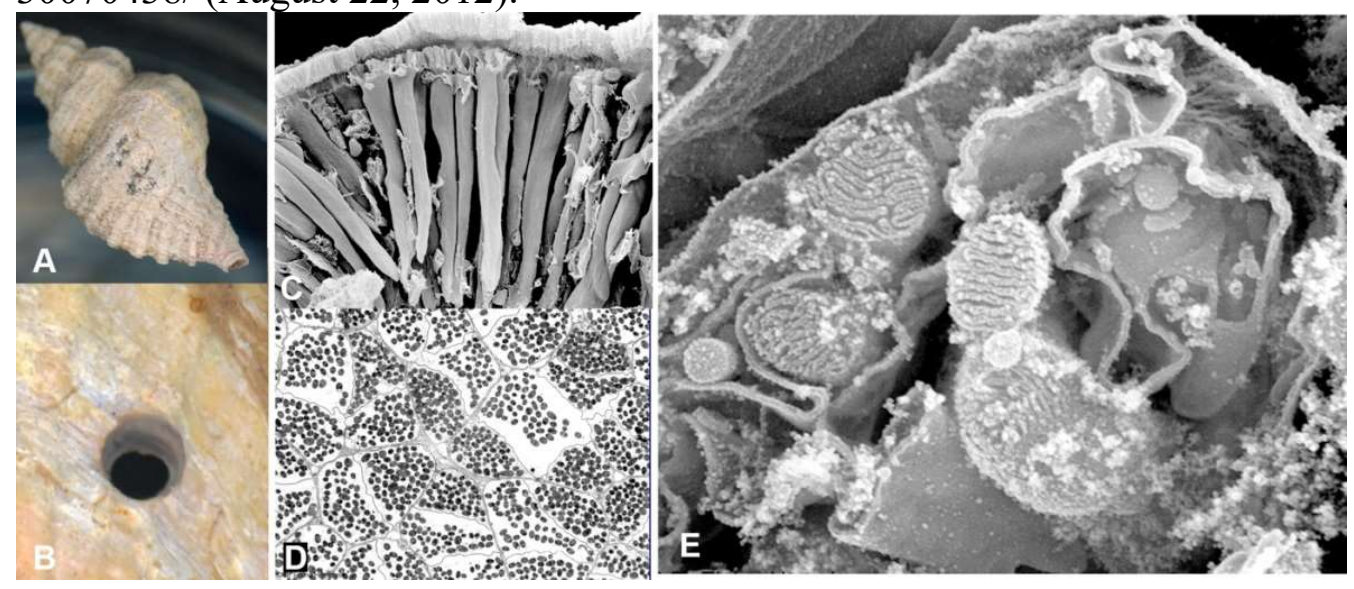

Figure 1. Ocenebra erinacea and the accessory boring organ showing mitochondria in TEM and SEM. A. Ocenebra erinacea B. hole bored in oyster C. columns in ABO D. cross section of ABO columns showing numbers of mitochondria in TEM E. cross section of mitochondria in SEM 